\title{
A tear fault boundary between the Taiwan orogen and the Ryukyu subduction zone
}

\author{
Serge E. Lallemand ${ }^{\mathrm{a}, *}$, Char-Shine Liu ${ }^{\mathrm{b}}$, Yvonne Font ${ }^{\mathrm{a}}$ \\ ${ }^{a}$ UMR CNRS-UM2 5573, Laboratoire de Géophysique et Tectonique, ISTEEM, Case 60, place E. Bataillon, 34095 Montpellier, France \\ ${ }^{b}$ Institute of Oceanography, National Taiwan University, P.O. Box 23-13, Taipei, Taiwan
}

Received 8 February 1996; accepted 4 October 1996

\begin{abstract}
More than twenty seismic lines were analysed across the intersection of the Taiwan orogen and the Ryukyu arc-forearc system. The main results of this study concern the recognition of two superposed sedimentary basins that were previously unknown. We have named the recent one the Hoping Basin and the older, tectonized one the Suao Basin. The Suao Basin, containing sediments more than $3 \mathrm{~km}$ thick, records subsidence of about $3 \mathrm{~km}$ on its southwestern portion after being shortened in the direction of plate convergence. On the basis of seismicity, gravity, present-day plate kinematics as well as seismic reflection data, we relate the dramatic subsidence of the Suao Basin to the initiation of a WNW-trending tear fault within the Philippine Sea plate. This tear fault decouples the subducting Philippine Sea plate to the northeast and the apparent overthrusting Philippine Sea plate in the Coastal Range to the southwest. Back-arc rifting may thus occur in the westernmost section of the Okinawa trough above the sinking Philippine Sea slab while lithospheric shortening prevails south of Hualien. As a consequence, the triangular area located southwest of the tear fault, between the Taiwan coastline and the toe of the Yaeyama ridge, no longer belongs to the Ryukyu forearc. It is now passively transported with the non-subducting portion of the Philippine Sea plate. We propose an evolutionary model for the relative chronology of tectono-sedimentary events in this region over the last 5 m.y.
\end{abstract}

Keywords: Taiwan; arc-continent collision; Ryukyu subduction zone; Coastal Range of Taiwan; tear fault; subsidence

\section{Geodynamic setting}

The orogen of Taiwan is often cited as a reference one, because it is actively deforming (e.g. Wu, 1978; Wu et al., 1991), propagating southward (e.g. Suppe, 1981; Barrier, 1985), and the motion of major plates is reasonably well constrained. At present, the Philippine Sea plate converges toward the Eurasia plate at a rate of $71 \mathrm{~km} / \mathrm{m}$.y. along an azimuth of

\footnotetext{
* Corresponding author. Phone: +33467 143-301. Fax: +334 67 523-908. E-mail: 1allem@dstu.univ-montp2.fr
}

$307^{\circ}$ (Seno et al., 1993). Teng (1990) suggested that the convergence occurred along a north-northwest azimuth, instead of the actual west-northwest, prior to $5 \mathrm{Ma}$. East of the island, the deformation front of the Ryukyu trench can be traced westward at least to $123^{\circ} \mathrm{E}$ (Fig. 1), whereas the Benioff zone of the subducting Philippine Sea plate is recognized somewhat farther west, to $121^{\circ} 15^{\prime} \mathrm{E}$, beneath northern Taiwan (Wu et al., 1991). Arc volcanism at the northernmost part of Taiwan and nearby offshore islands of the Ryukyu arc has been dated, using $\mathrm{K}-\mathrm{Ar}$ and fission tracks methods, at 0.5 to $3.6 \mathrm{Ma}$ (Juang and Bellon, 


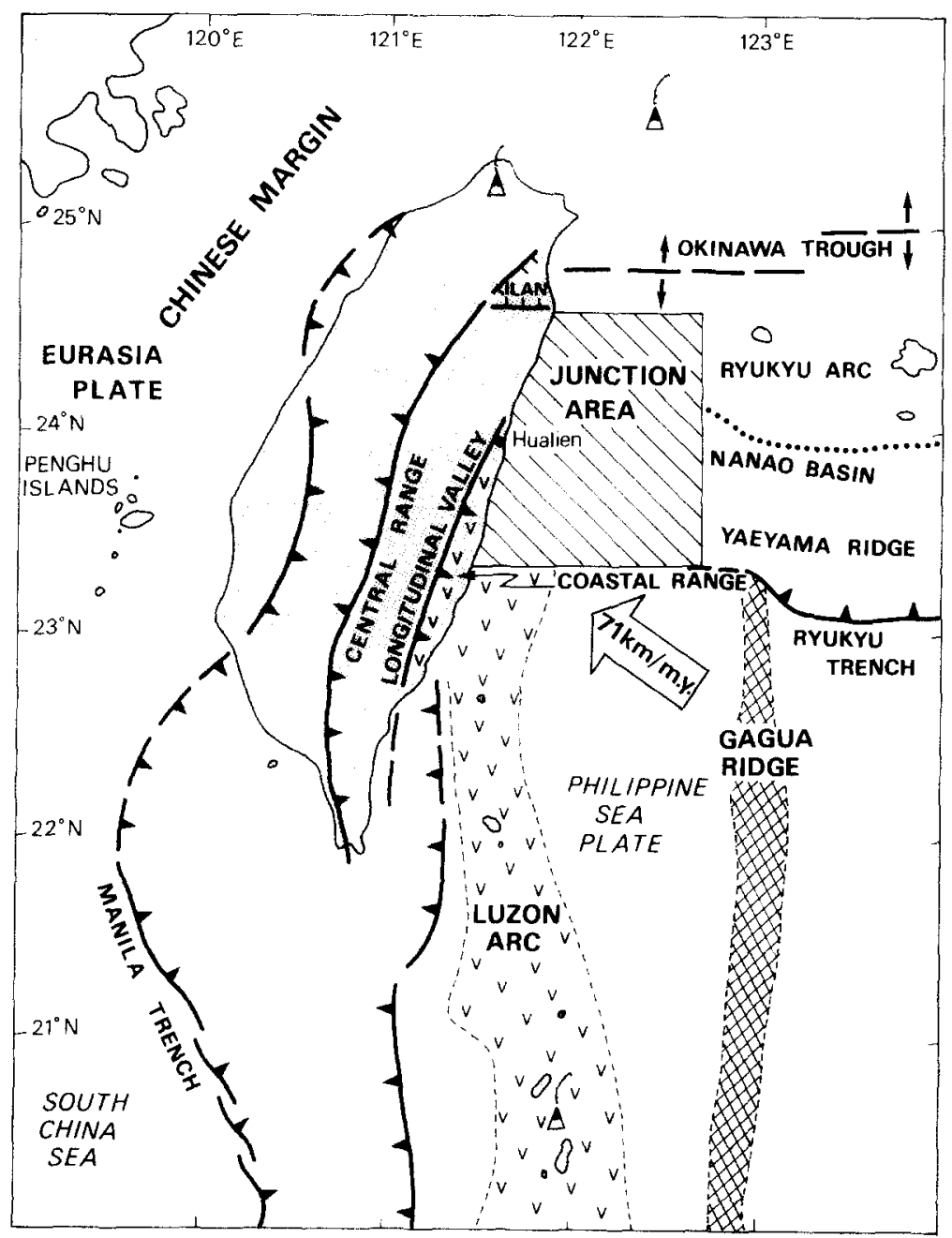

Fig. I. Geodynamic setting. location of the studied area: "junction area"

1984; Teng et al., 1992). The Plio-Pleistocene age for arc volcanism implies that subduction occurred in this area at least since the Pliocene as attested by the present $300 \mathrm{~km}$ depth of the slab deduced from seismicity (H. Kao and S.-S. Sheng, pers. commun., 1995). Igneous bodies cluster along a narrow zone (Teng et al., 1992) and confirm the steepness of the slab deeper than $100 \mathrm{~km}$. The Longitudinal Valley is considered to represent the boundary between the Philippine Sea plate, which carries the Luzon volcanic arc (Coastal Range), and the Eurasian plate (e.g. Barrier and Angelier, 1986).

Most authors agree that the recent phase of collision dates back to between 2.5 and $5.5 \mathrm{Ma}$ (Wu.
1978: Suppe. 1981; Angelier et al., 1990; Teng. 1990: Deramond et al., 1995) and an older collisional phase may have occurred during the Miocene (Teng, 1990; Lu and Hsu, 1992; Deramond et al.. 1995). The recent collisional event is dated by the formation of the Lichi mélange, which crops out in the southern part of the Coastal Range (2.5 to $5.5 \mathrm{Ma}$; e.g. Chi et al., 1981; Barrier and Müller, 1984; Huang et al., 1995), by the more recent unconformity observed in the western Taiwan foothills (3 Ma; Lu and Hsu, 1992; Deramond et al., 1995), and by clockwise rotation of the northern part of the Coastal Range (3 Ma; Lee et al., 1991). The first Miocene orogenic event $(8 \mathrm{Ma})$ is attributed to the 
collision between the Central Range (or Gutaiwan Block or Tananao Complex) of continental affinity and the Chinese margin, whereas at present, the active collision occurs between the northern Luzon arc (or Coastal Range) and Eurasia ( $\mathrm{Lu}$ and Hsu, 1992).

Continuous GPS monitoring between 1992 and 1994 shows that, in the area south of Hualien, about $3 \mathrm{~cm} / \mathrm{yr}$ of convergence is accommodated along the Longitudinal Valley, 2 to $2.5 \mathrm{~cm} / \mathrm{yr}$ along the westernmost onland thrust, and between 0 and $2 \mathrm{~cm} / \mathrm{yr}$ of shortening between the western coast of the island and the Penghu Islands (Yu and Chen, 1994; Yu et al., 1995). Thus, there is not a single plate boundary in the southern part of the island, but instead there are several active thrusts on which a significant amount of shortening is accommodated. In central Taiwan, the instantaneous shortening between the major plates seems to be totally accommodated onland, so little or no deformation within the Philippine Sea plate is expected to the east of the collision zone. Slightly south of the Ilan Plain near the northeast coast (see Ilan in Fig. 1), NW-SE extension of a few $\mathrm{cm} / \mathrm{yr}$ is measured. The northwestern part of the island is almost stable, with respect to the Chinese margin, according to GPS measurements.

The plate boundary must be contorted north of the Coastal Range because the same plate, i.e. Philippine Sea plate, apparently overthrusts or pushes the Central Range along the NNE-SSW-trending Longitudinal Valley (Barrier, 1985), while it underthrusts the E-W-trending Ryukyu arc. The transition from one mode of thrusting to the other occurs in a very complex area restricted to only about $10,000 \mathrm{~km}^{2}$, which we will call the 'junction area'. Some authors have proposed tectonic models supported by seismicity (e.g. Wu, 1978; Wu et al., 1991, 1994) or physical experiments (Shemenda, 1994; Chemenda, 1995), but no previous models have been constrained by seismic lines in the 'junction area'. Several marine geophysical cruises have been devoted to this critical 'junction area' east of Hualien since 1984 (e.g. Liu et al., 1997). More than twenty seismic lines, in this relatively small area, have been analysed and allow us to propose an evolutionary model that satisfies all the previous geophysical constraints, such as provided by seismicity, gravity and presentday kinematics, as well as the seismic lines.

\section{Results from recent marine surveys}

Twenty-four seismic lines (see Fig. 2 for locations), obtained during five seismic cruises, were analyzed in the 'junction area' just off Hualien (Stéphan et al., 1990; Lin, 1994; Liu et al., 1997). Also, a new bathymetric map has been compiled, which is particularly useful in this very complex area (Fig. 2). A description of the regional seismic structure and tectonic setting, based on most of these lines, will be presented by Liu et al. (1997). The major results are summarized in this paper and illustrated with two orthogonal multi-channel seismic lines: $367-07$ (see Fig. 3) and 423-25 (Fig. 4), and one single-channel line: 360-29 (Fig. 6).

\subsection{Morphostructure of the 'junction area'}

The southwestern non-volcanic Ryukyu arc and the Yaeyama ridge, which is inferred to be an accretionary wedge, are progressively offset northwards as they approach Taiwan Island (Fig. 2). The westernmost offset of the steep southern flank of the arc reaches nearly $30 \mathrm{~km}$ resulting in a NNW-SSEtrending trough (the Hoping Basin in Fig. 2). A major E-W-trending spur, about $1.2 \mathrm{~km}$ high above the adjacent seafloor, and called the Hsincheng ridge, projects eastward into the middle of the trough. East of the major N-S offset of the arc, the Nanao forearc basin is trapped between the southward-dipping Ryukyu arc basement and the Yaeyama ridge. The Hualien Canyon runs from north to south between the eastern flank of the Coastal Range and the western edge of the Yaeyama ridge. The canyon floor lies 1 to $1.5 \mathrm{~km}$ beneath the crest of the Yaeyama ridge, and it ends in the Ryukyu trench south of the ridge. The trench floor, the Yaeyama ridge and the forearc basins all decrease in water depth westward, near Taiwan, suggesting that the underlying Philippine Sea plate also shallows from $123^{\circ} \mathrm{E}$ to the coast of the island. The terracing of the forearc basins (4.6 $\mathrm{km}$, East Nanao Basin, about $150 \mathrm{~km}$ east of Taiwan; $3.7 \mathrm{~km}$, West Nanao Basin, about $100 \mathrm{~km}$ east of Taiwan; and $3.0 \mathrm{~km}$, Hoping Basin, about $50 \mathrm{~km}$ east of Taiwan) is similar to those observed on the inner wall of the Izu-Bonin arc near the trench-trenchtrench triple junction, south of Tokyo (e.g. Huchon and Labaume, 1989). 


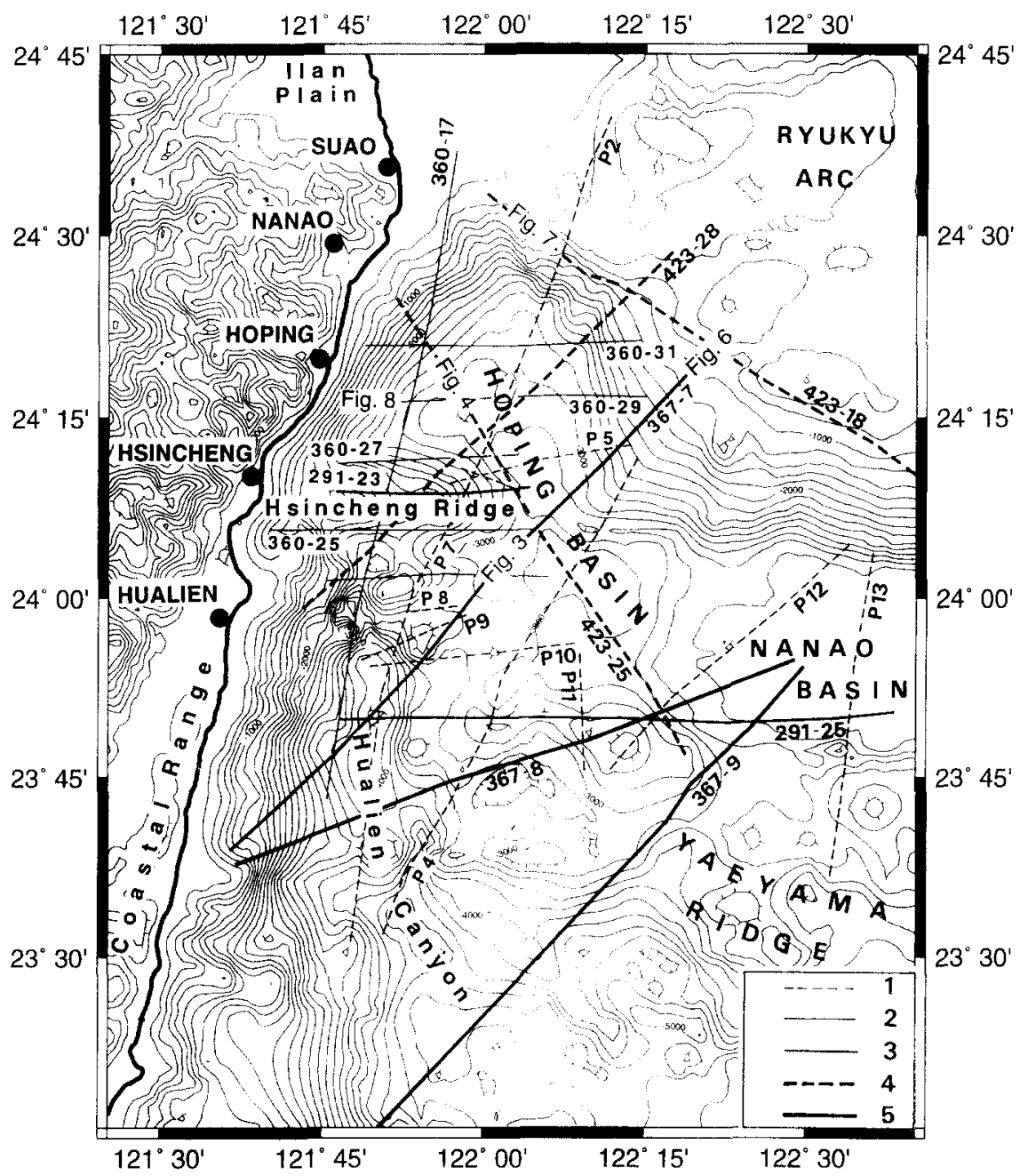

Fig. 2. Location of the profiles used in this study (24 lines: POP2-P2/4/5/6/7/8/9/10/11/12/13, ORI 360-31/29/27/25/23, ORI 291-23/25, ORI 367-7/8/9 and ORI 423-18/25/28). Only 3 lines will be shown in this paper: 367-7. 360-29 and 423-25. The bathymetric map is contoured every $200 \mathrm{~m}$. Legend: $I=$ single channel line; $2=4$-channel line; $3=24$-channel line; $4=52$-channel line; $5=56$-channel line.

\section{Seismic reflection characteristics of the Hoping and Suao Basins}

Most of the E-W or NE-SW seismic lines (Fig. 2) across the trough show the same seismic pattern as revealed by line 367-07 (Fig. 3). We observe a thick southwest-dipping sedimentary sequence (Unit $B$ in Fig. 3) extending from top of the Ryukyu arc down beneath near-horizontal strata of another basin, which fills the trough (Unit A in Fig. 3). The older, tilted basin is here named the Suao Basin, while the overlying younger basin is named the
Hoping Basin, after the names of two nearby cities, respectively, on Taiwan. The two NW-SE-trending seismic lines (423-18 and 423-25) demonstrate that the Suao Basin was folded, and probably thrust. before being covered by strata of the Hoping Basin (Fig. 4).

After analysing all the available seismic lines, we are now able to outline the Hoping Basin. The basin is $70 \mathrm{~km}$ long, elongate along a N-S direction between latitudes $23^{\circ} 50^{\prime} \mathrm{N}$ and $24^{\circ} 25^{\prime} \mathrm{N}$, and $45 \mathrm{~km}$ wide. Sediments within the basin reach a thickness of 1.8 s TWT (two-way-travel time; Fig. 5a) and the 

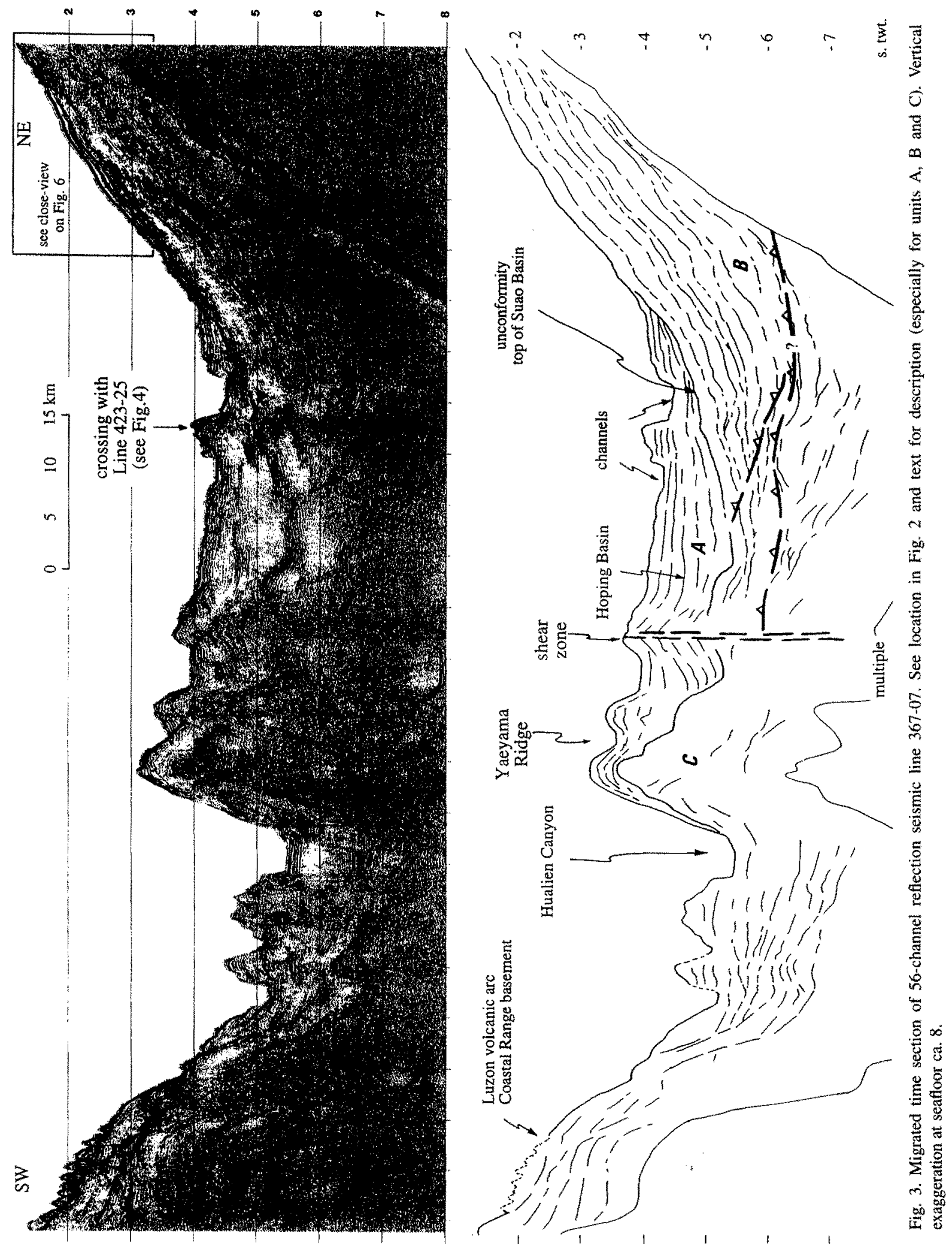

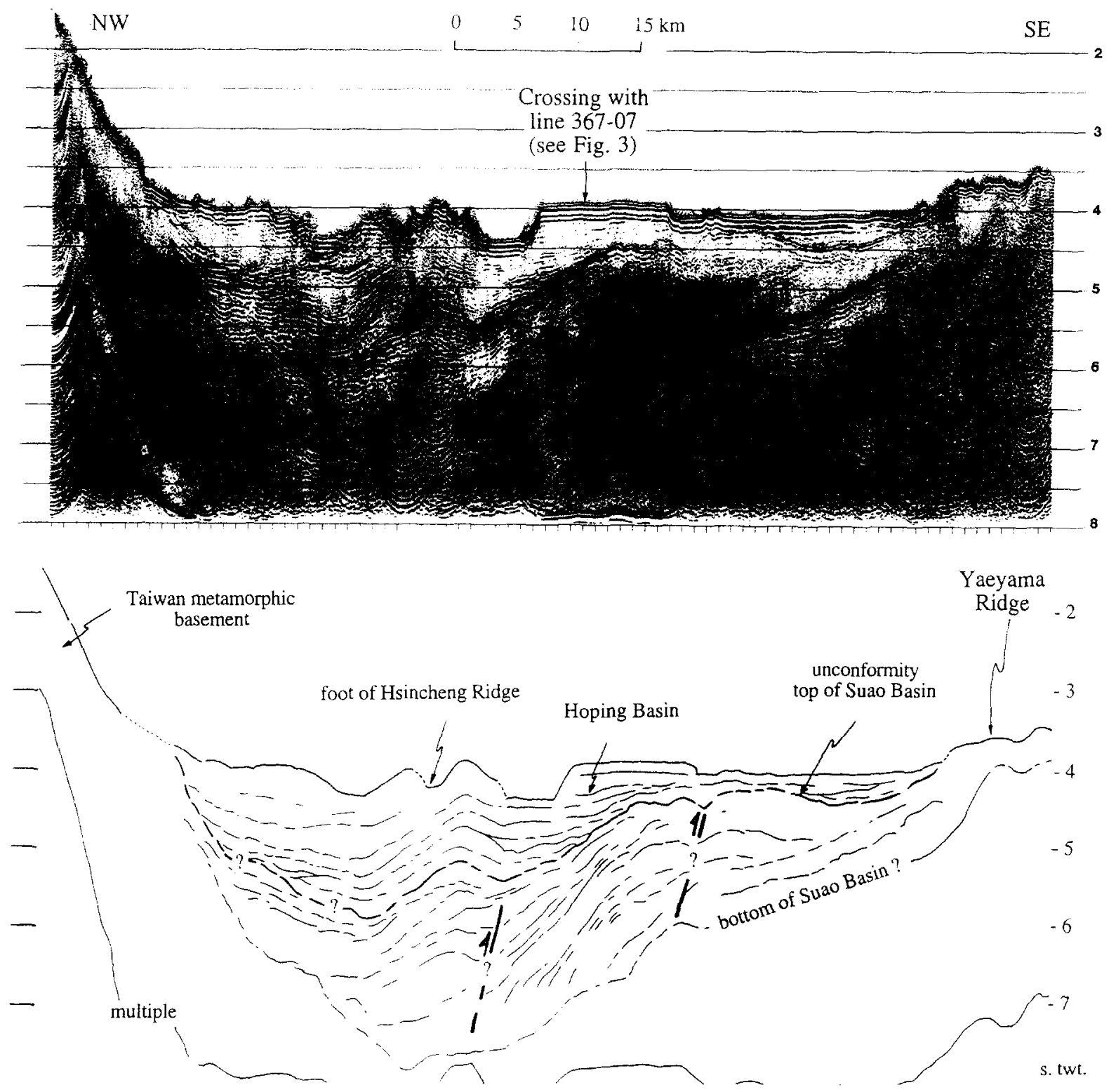

Fig. 4. Migrated time-section of 52-channel reflection seismic line 423-25. See location in Fig. 2 and text for description. Vertical exaggeration at seafioor ca. 8 .

average water depth of its floor is $3000 \mathrm{~m}$. The Hoping Basin unconformably overlies deformed strata of the Suao Basin, as seen in Figs. 3 and 4. The nature of the substratum is less clear beneath the western part of the basin. This region corresponds morphologically to the Yaeyama ridge, but the ridge may

Fig. 5. Isopach maps of the Hoping Basin (a) and Suao Basin (b); contour interval $0.5 \mathrm{~s}$ TWT. Dashed lines represent presumed contours where there are ambiguities in seismic interpretation. They are extrapolated from the overall shape of the basin. The dotted line in (a) represents the surface boundary between active deformation to the southwest (grey pattern) and no active deformation to the northeast based on seismic lines analysis. 

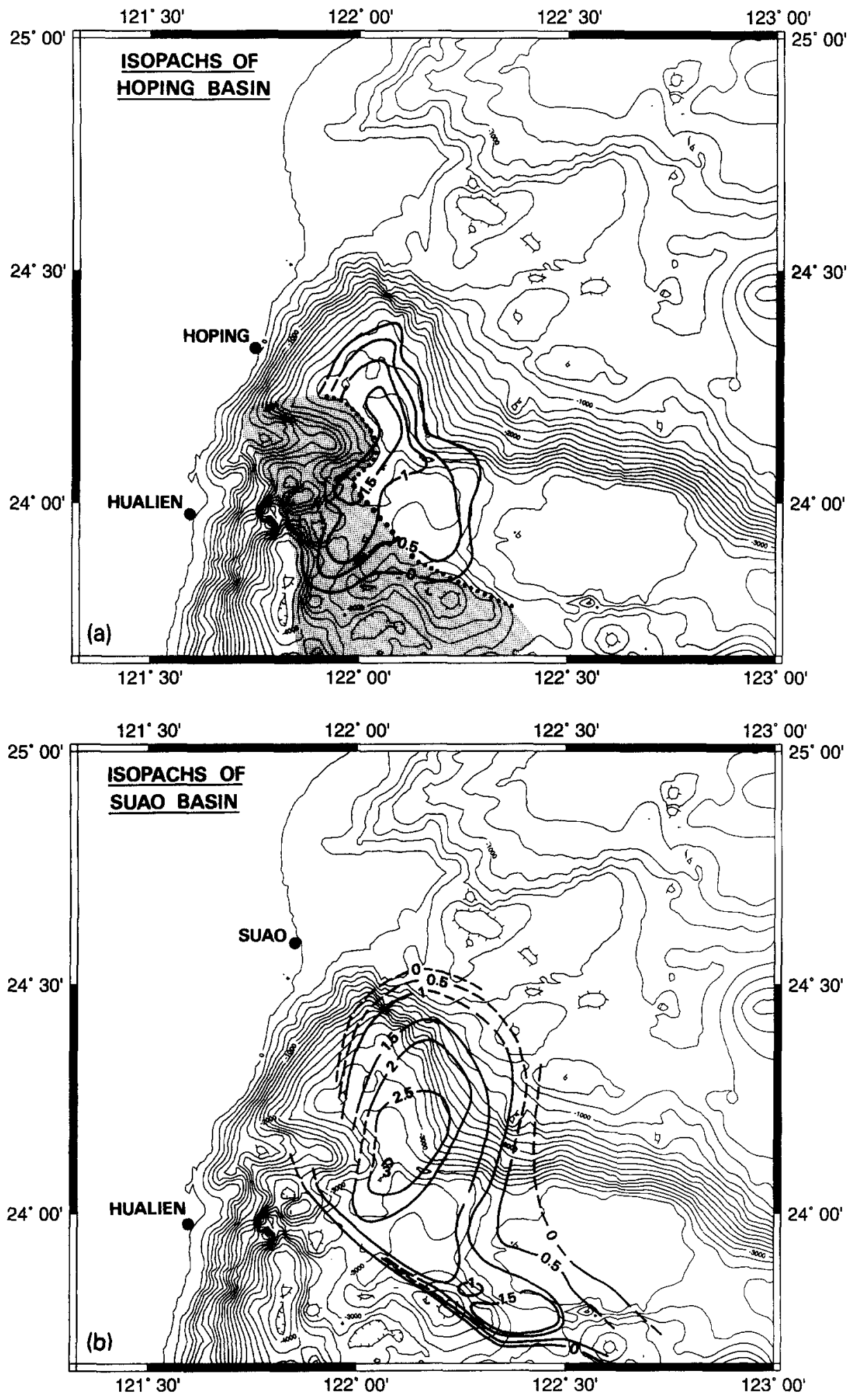


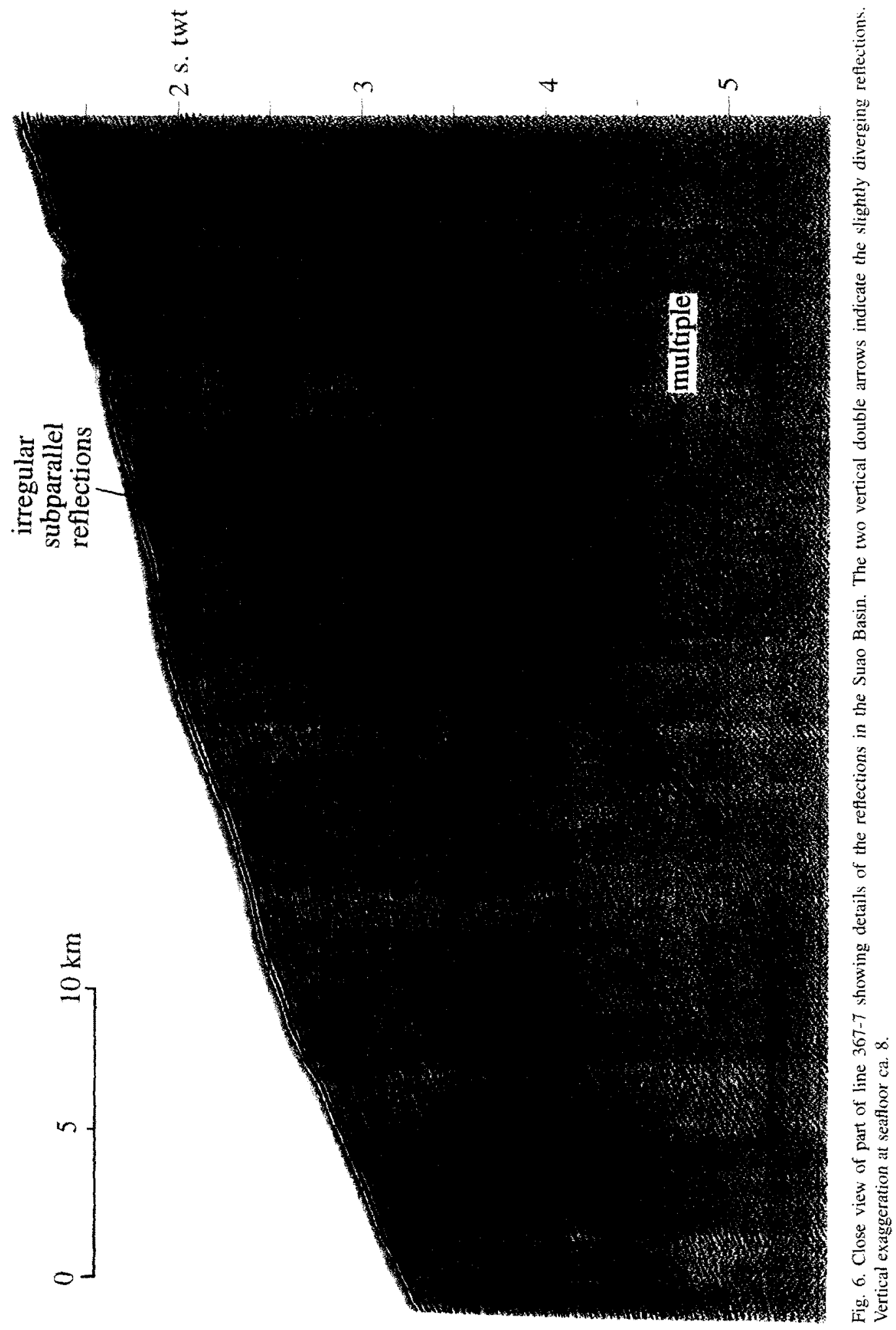


not necessarily represent an accretionary wedge in this region, as it could also be the basement of the Hsincheng ridge or the deformed Suao Basin (Unit $\mathrm{C}$ in Fig. 3). To the southeast, the Hoping Basin laps onto the Yaeyama ridge. These strata are less than $1 \mathrm{~s}$ TWT thick and may have originated from ancient canyon levees. The southwest region of Hoping basin has been uplifted and deformed while the rest of the basin has remained stable (Fig. 3). On the basis of seismic lines, we were able to trace some U-shaped submarine canyons, several hundred metres deep, across the Hoping Basin. These canyons are presently erosive (no levees) rather than depositional and we can find evidence, in the subsurface, of former canyons that are presently filled. The southwestern modern canyon is a tributary of the Hualien Canyon which supplies detritus to the trench while the main one ends in the Nanao forearc basin, 700 $m$ deeper than the Hoping Basin. The Nanao Basin is filled with turbidites as attested by the continuous sub-parallel reflections (Liu et al., 1997). Most of the seismic profiles across the Hoping Basin show hummocky reflections (cross-stratification) as well as remnants of ancient canyons typical of high-energy environments (Fig. 6). Both the uplift of the southern side of the basin and the numerous canyons observed cutting through but not ending in the basin, suggest that the Hoping Basin is no longer filling. On the contrary, the Nanao Basin, which is farther from the coast than the Hoping Basin, is supplied by turbidites probably coming from the Lan-Yan River (Ilan Plain).

The main part of the Suao Basin is about 70 $\mathrm{km}$ long and $50 \mathrm{~km}$ wide, mainly $\mathrm{N}-\mathrm{S}$-trending (Fig. 5b). The maximum sediment thickness of $3 \mathrm{~s}$ TWT is recorded at the foot of Hsincheng ridge. This is a minimum thickness because of the limits in seismic penetration and also because of the water bottom multiple, which masks deeper reflections. Reflections are irregular, subparallel and discontinuous (see enlargement in Fig. 6). The imaged strata are interpreted as small interdigitized progradation lobes or lenses typical of platform or prodelta sedimentation. This basin extends from the top of the Ryukyu arc to the 'junction area' off Hualien, the uppermost layer of the basin corresponding to the flank of the arc. All the strata are tilted to the southwest by up to $5^{\circ}$ (Fig. 3) and to the west, in the northern portion of the basin, by up to $11^{\circ}$ (see line 360-29 in Fig. 8). Locally, in the northernmost portion of the basin, strata dip southward $7^{\circ}$ along line P2 (see location in Fig. 2). Assuming that these strata were deposited horizontally, either the northeastern side of the basin was uplifted by approximately $3 \mathrm{~km}$, or the southwestern side subsided by the same amount.

Examining details of the reflections (Fig. 6), one may observe slightly diverging reflections, which can be attributed to either syn-sedimentary compaction or syn-sedimentary differential vertical motion, the main vertical event occurring after deposition of the uppermost strata. Compaction may likely have occurred because of the increasing thickness of sediment toward the centre of the basin (Fig. 5b). The nature of the basement of the Suao Basin remains unknown. The basin ends abruptly along its southwestern side against a possible shear zone which affects the Yaeyama ridge (Fig. 3). The location of the shear zone is not only deduced from line 367-7 but it also intersects lines 367-8 and 367-9 (see locations in Fig. 2, Lallemand et al., 1995; Liu et al., 1997). The possible shear zone is subparallel to the direction of plate convergence and might act as a transform fault within the Yaeyama ridge. Folding of Suao Basin strata is observed on top of the Ryukyu arc on line 423-18 (Fig. 7) as well as in the portion sealed by the Hoping Basin (Fig. 4). Thrusting is highly probable beneath the Hoping Basin (Fig. 4). Because folded strata have a maximum wave amplitude along NW-SE transects (Fig. 4 for example) and are not recognized along NE-SW transects (Fig. 3 for example), we deduce that fold axes trend WSW-ENE (Fig. 8).

Both basins are presently in a forearc position relative to the Ryukyu trench and arc but they are not typical turbidite-filled forearc basins. They have undergone a complex tectonic and sedimentary evolution that is likely related to the past and ongoing arc-continent collision.

The Hsincheng ridge is overlain by highly deformed sediment that can be attributed to the Hoping or Suao basins. South of the ridge, it is possible to trace, from one seismic line to another, an area which is actively deforming southwest of a NW-SE line which corresponds to the rear of the Yaeyama ridge (dotted line in Fig. 5a). This NW-SE transition zone has been interpreted as a strike-slip fault 


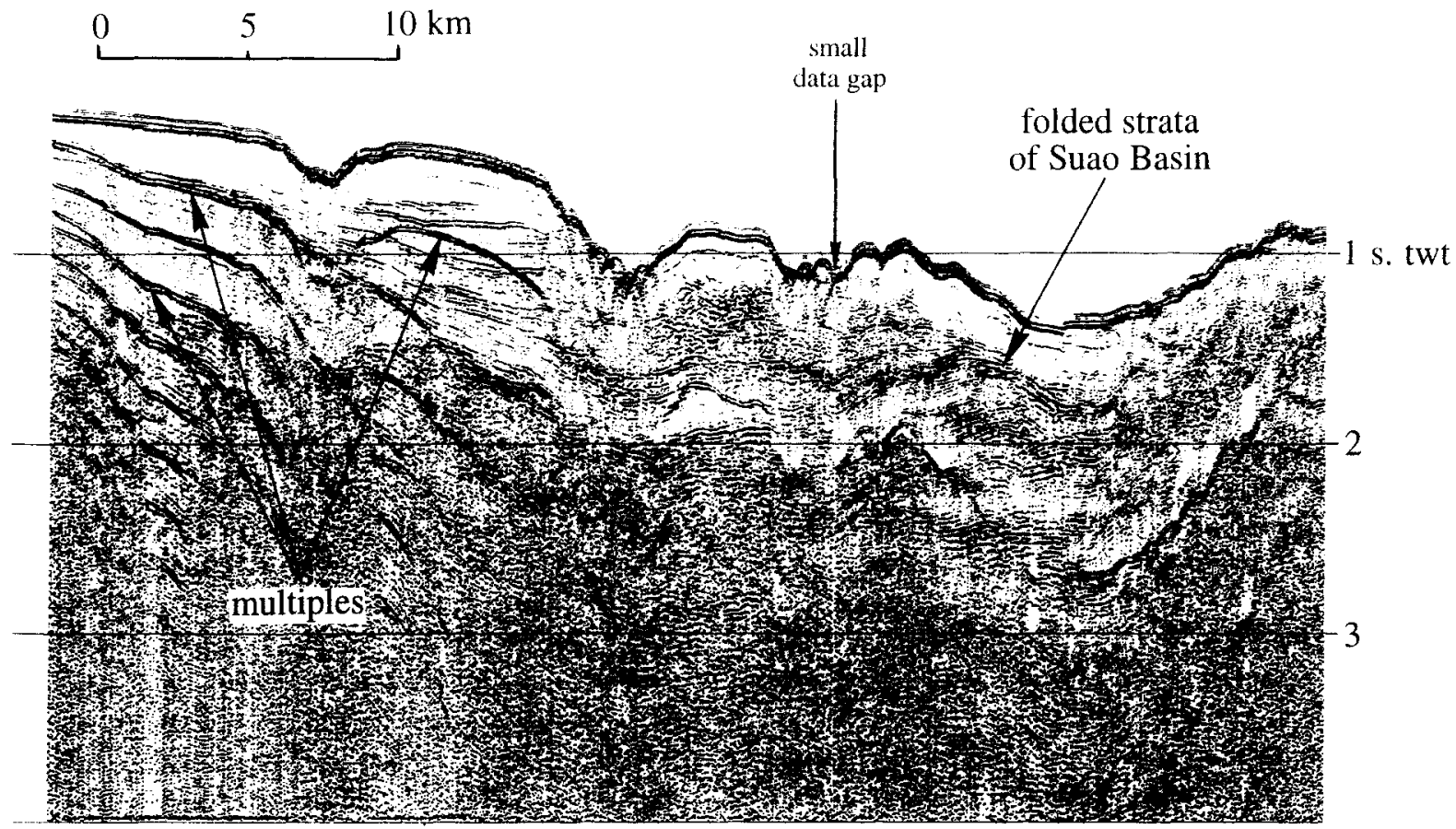

Fig. 7. Part of near-trace seismic section 423-18 showing folded strata on top of the Ryukyu arc. See location in Fig. 2. Vertical exaggeration at seaftoor ca. 8 .

by Lallemand et al. (1995) and Liu et al. (1997). In general, the whole area located just southwest of this strike-slip fault is deformed and/or uplifted by several hundreds of metres, while north of this line. no active deformation has been observed.

The axis of the active Hualien Canyon is filled with 1.5 to $2 \mathrm{~s}$ TWT of sediment. The slope on the west side of the line (Fig. 3) corresponds to the flank of the Coastal Range, while the $1500 \mathrm{~m}$ high steep wall on the east side of the canyon in Fig. 3 is inferred to be the result of erosion of the Yaeyama ridge by turbidity currents in addition to tectonic deformation.

\section{Tectono-sedimentary evolution of the Hoping and Suao Basins}

\subsection{The subsidence of the Suao Basin}

We interpret that the strata of the Suao Basin were not deposited on slopes dipping from 5 to $11^{\circ}$. but have been tilted toward the southwest except in the northern part where it is conformable to the south- and west-dipping are slopes. If so, then two questions should be addressed: (1) Did the Suao Basin experience uplift on its northeastern side or subsidence on its southwestern side? (2) Did the folding and thrusting of Suao Basin strata occur before, during or after tilting of the basin?

There are two main arguments in favour of subsidence of the Suao Basin. (1) The reflections show progradation lobes or lenses, typical of platform or prodelta sedimentation, which suggests that the deposition occurred in shallow waters. (2) It would be a striking coincidence if the uplifted part of the basin just coincides with the mean regional level of the Ryukyu arc. Folds and thrusts affect the whole Suao Basin, from the top of the arc at $500 \mathrm{~m}$ depth to the deepest point of the 'junction area' at $3500 \mathrm{~m}$ depth, and do not affect the strata of the overlying Hoping Basin, except in the vicinity of the Hsincheng ridge. We thus conclude that the shortening occurred before 


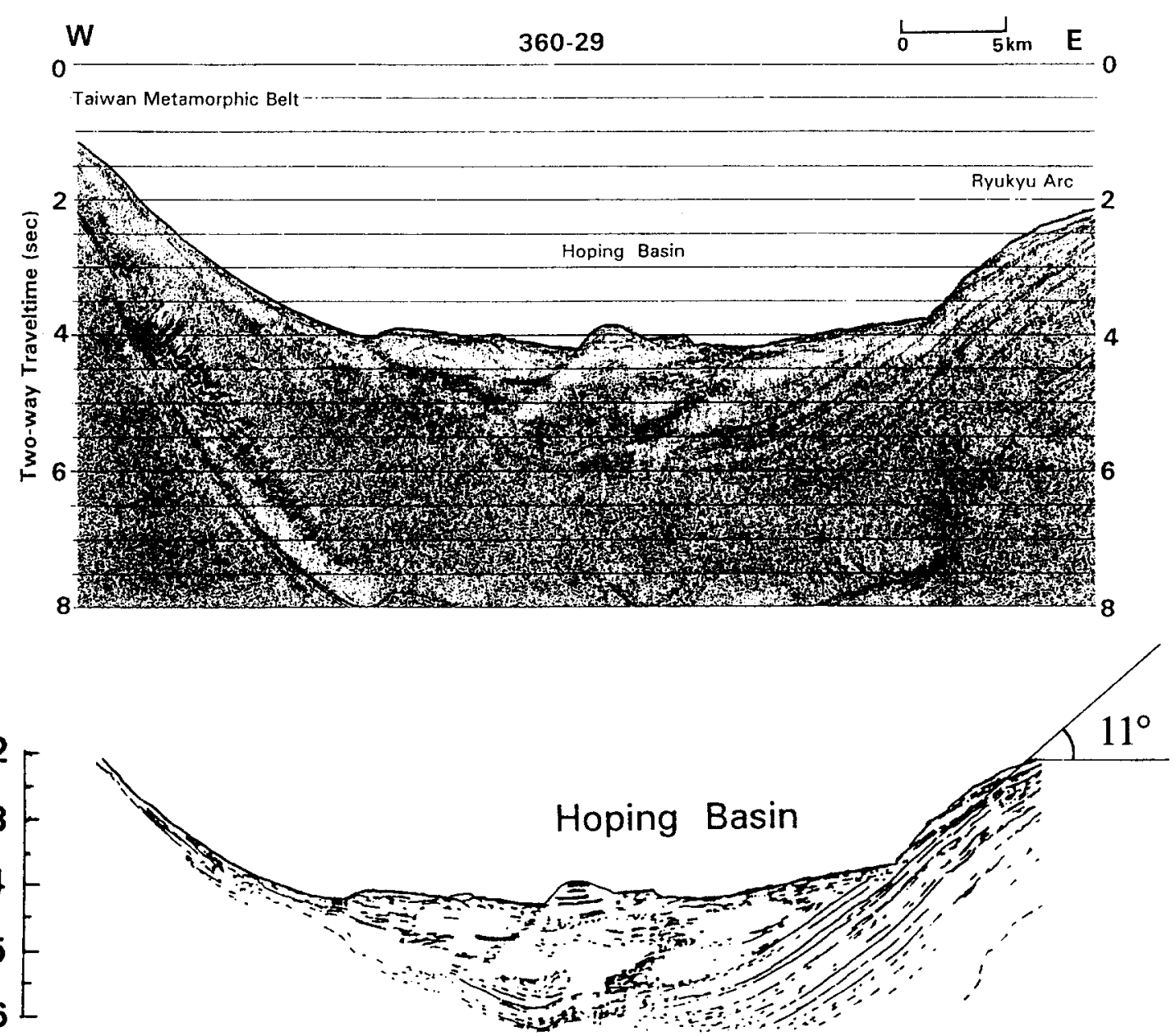

Fig. 8. Migrated time-section of 4-channel reflection seismic line 360-29. See location in Fig. 2 and text for description. The upper strata make the structural slope, so there is no need of correction of seismic velocities to determine the dipping of the strata $\left(11^{\circ}\right)$.

the deposition of the Hoping Basin strata, but there is no solid argument to better constrain the timing of the main phase of compressive deformation.

\subsection{The tear fault hypothesis}

What are the driving forces that allowed the Suao Basin to shorten in a SE-NW direction and subside on its southwestern portion by more than $3 \mathrm{~km}$ ? We propose that a NW-SE tear fault, sub-parallel to the convergence vector, accounts for the transition between overthrusting of the Philippine Sea plate on top of the Asian continental margin to the southwest of this tear fault boundary and underthrusting of the Philippine Sea plate beneath the Ryukyu arc to the northeast of this fault boundary (Figs. 9 and 10). The main subsidence phase can thus be attributed to abrupt sinking of the subducting plate on the northeastern side of the lithospheric fault. The former compressive phase can thus either be related to the first stages of collision or to initiation of subduction. The portion of the Philippine Sea plate just southwest of the tear fault continues to act as a buttress with respect to the converging passive margin of China. Both the 'buttress part' and the 'subducting part' of the Philippine Sea plate act as a single plate $150 \mathrm{~km}$ from Hualien as attested by the absence of intra-plate deformation.

In spite of the morphological extension of the Longitudinal Valley fault north of Hualien, there is 


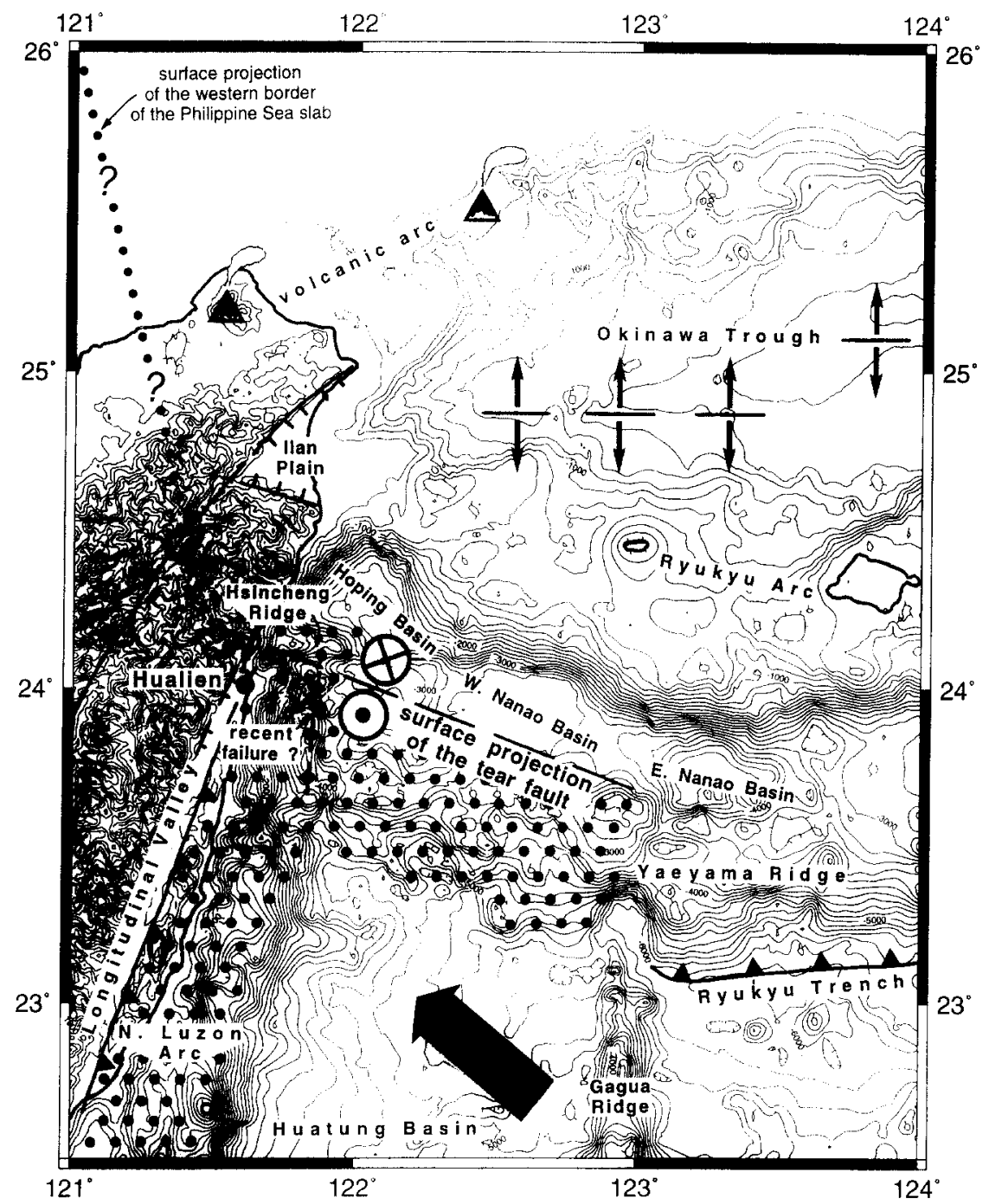

Fig. 9. Bathymetric map of the "junction area". Isobaths every $10(0) \mathrm{m}$. Tectonic interpretation superimposed on the map with surface projection of the tear fault which probably propagates toward the southeast. On both sides of the presumed tear fault, open circles with dot or cross indicate the sense of vertical motion along the fault. The dotted area corresponds to the area of active deformation. The dotted NNW-trending line with question marks represents the surface trace of the western subducting Philippine Sea plate (deduced from epicentres of earthquakes) which could be an old transform fault (see Fig. 13). The solid arrow indicates the relative plate motion. The possible recent failure of the Philippine Sea plate is indicated by dashed lines with triangles on both sides, because we ignore what could be the thrust vergence (to the east according to Chemenda (1995). based on physical modelling and seismicity; to the west according to surface expression, based on seismic lines across the areal.

evidence that the plate boundary may have migrated southward of Hualien in very recent time according to GPS data (Yu et al.. 1995), seismicity (Yeh et al., 1991) and onland tectonic observations (Angelier et al., 1995). At a regional scale, GPS data show that the northern part of Taiwan is now stable (Yu et al., 1997), attesting that the collision is no longer active at these latitudes. As a consequence, the compressive stress has been released, indicating that there must be a subduction zone off Hualien that accommodates all of the Philippine Sea-Eurasia plate convergence. According to seismic lines, the only visible active deformation front is at the foot of the Yaeyama ridge either along $23^{\circ} 10^{\prime} \mathrm{N}$ compatible 


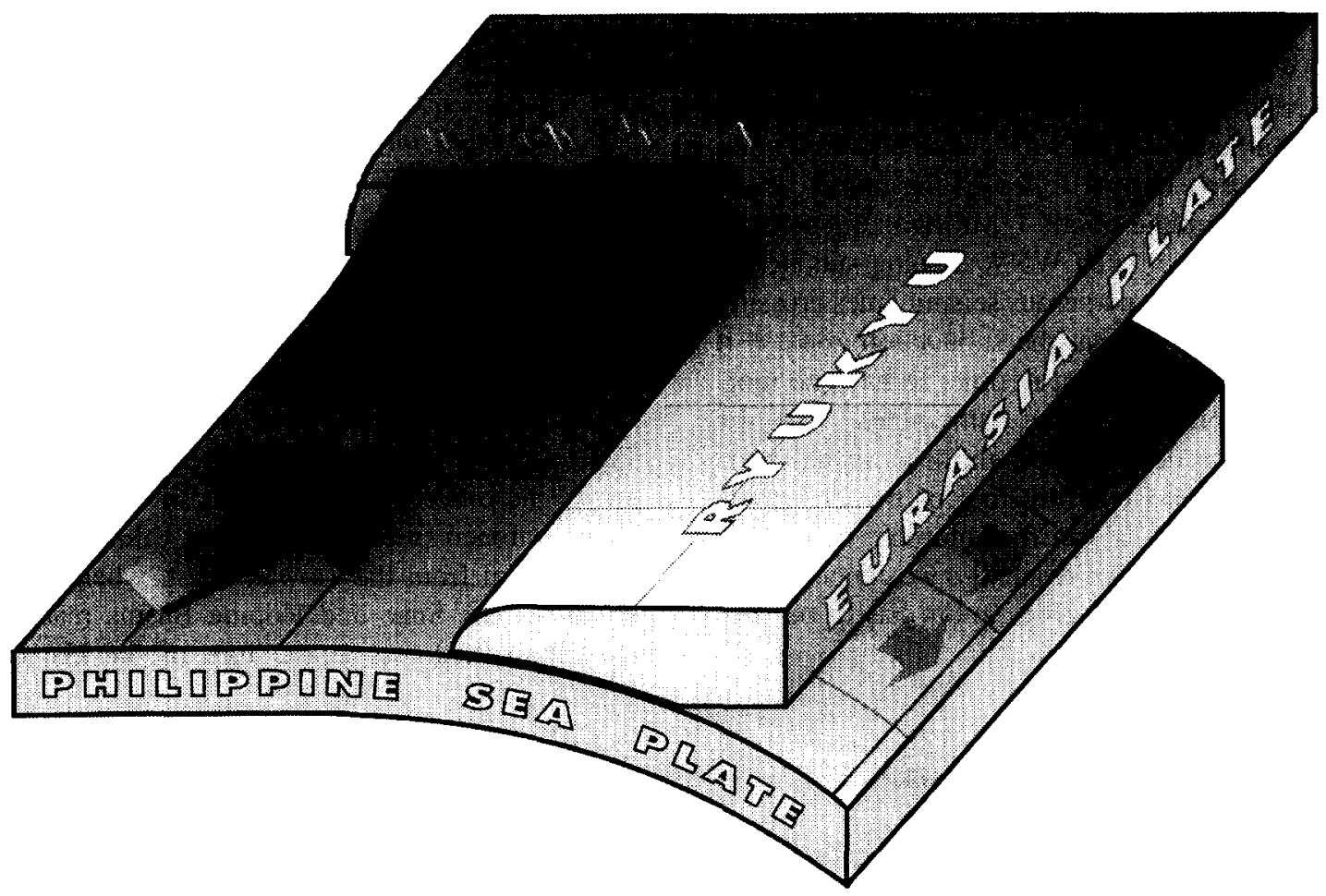

Fig. 10. General 3D-sketch of the 'junction area' illustrating the tear fault hypothesis. View from the northeast. Sediments from the Hoping and Suao Basins have been removed intentionally to point out the tear fault.

with a south-vergent subduction along the westernmost Ryukyu trench, or along $121^{\circ} 50^{\prime} \mathrm{E}$ compatible with a west-vergent subduction along the Hualien Canyon. However that may be, active deformation is attested by seismic lines in the southwestern part of the basins, whereas no deformation is observed in the northeastern part of the Hoping Basin (Fig. 5a). Therefore, we infer that the surface projection of the tear fault coincides with the Hsincheng ridge and extends toward the east-southeast, subparallel to the convergence vector (see Fig. 9). As a consequence, the triangular area located between the Hualien Canyon, the Ryukyu trench and the tear fault no longer belongs to the Ryukyu plate but rather to the Philippine Sea plate. The northernmost tip of the Philippine Sea plate must undergo clockwise crustal block rotations to account for GPS observations. The Ryukyu deformation front thus probably ends coincidentally (?) near the junction between the trench and the Gagua ridge.

If the tear fault initiation was 'old', one may expect some buckling of the lithosphere east of the
Coastal Range to accommodate the convergence, but no deformation is observed in that area (unpublished reflection seismic data) even if the stress field is compressive in the direction of convergence (Cheng et al., 1995). Consequently, because the Philippine Sea plate (excluding the arc) does not deform significantly in the Huatung Basin where it is observable, we infer that: (1) the tear fault was initiated no more than 2 to 3 m.y. ago; (2) part of the convergence is absorbed by shortening of the active orogen as attested by GPS data and part is absorbed through the internal deformation of the arc attested by the very high level of seismicity. Failure between the tear fault and the Longitudinal Valley may have occurred in very recent times $(0.1-0.2 \mathrm{Ma})$ within the Philippine Sea plate at the base of the Coastal Range, initiating from the tear fault and propagating southward, to both explain the relative stability of the Hualien region compared with the rest of the Coastal Range (geodetic data, Yu et al., 1995) and the very high level of seismicity in the same region (Yeh et al., 1991). Such a failure and incipient sub- 
duction of the Philippine Sea plate under northeast Taiwan were proposed by Shemenda (1994), based on the results from physical modelling. According to these authors, a rapid subsidence and formation of a 'subduction trench' followed the failure of the Philippine Sea plate about $1 \mathrm{Ma}$ ago. Because no surface evidence of such WNW-dipping subduction zone exists from the numerous seismic lines crossing the area, we suggest that the subduction zone, if it exists, must be very recent in order to have no morphological expression in the bathymetry. Also, the tectonic style, as deduced from the seismic line interpretations, suggests overthrusting of the Philippine Sea plate onto the Taiwan metamorphic belt rather than underthrusting. Consequently, we conclude that a $\mathrm{N}-\mathrm{S}$ failure may exist (Fig. 9) but has to be very recent.

\section{Tear fault as a temporary unstable plate boundary}

\subsection{Additional constraints given by gravity}

A large negative free-air gravity anomaly of -190 mGals characterizes the area just east of Hualien (Bowin et al., 1978; Smith and Sandwell, 1995; Yen et al., 1995). This low extends to the eastsoutheast in the forearc area, decreasing in intensity to reach $-110 \mathrm{mGals}, 200 \mathrm{~km}$ east of Hualien (Fig. 11). Typical gravity lows along forearc basins and trench are of the order of $-100 \mathrm{mGals}$ in the extensional Ryukyu trench system. The lowest value is recorded only $35 \mathrm{~km}$ from the Taiwan coast, where the sediments of the Suao and Hoping Basins reach their maximum thickness at the foot of the Hsincheng

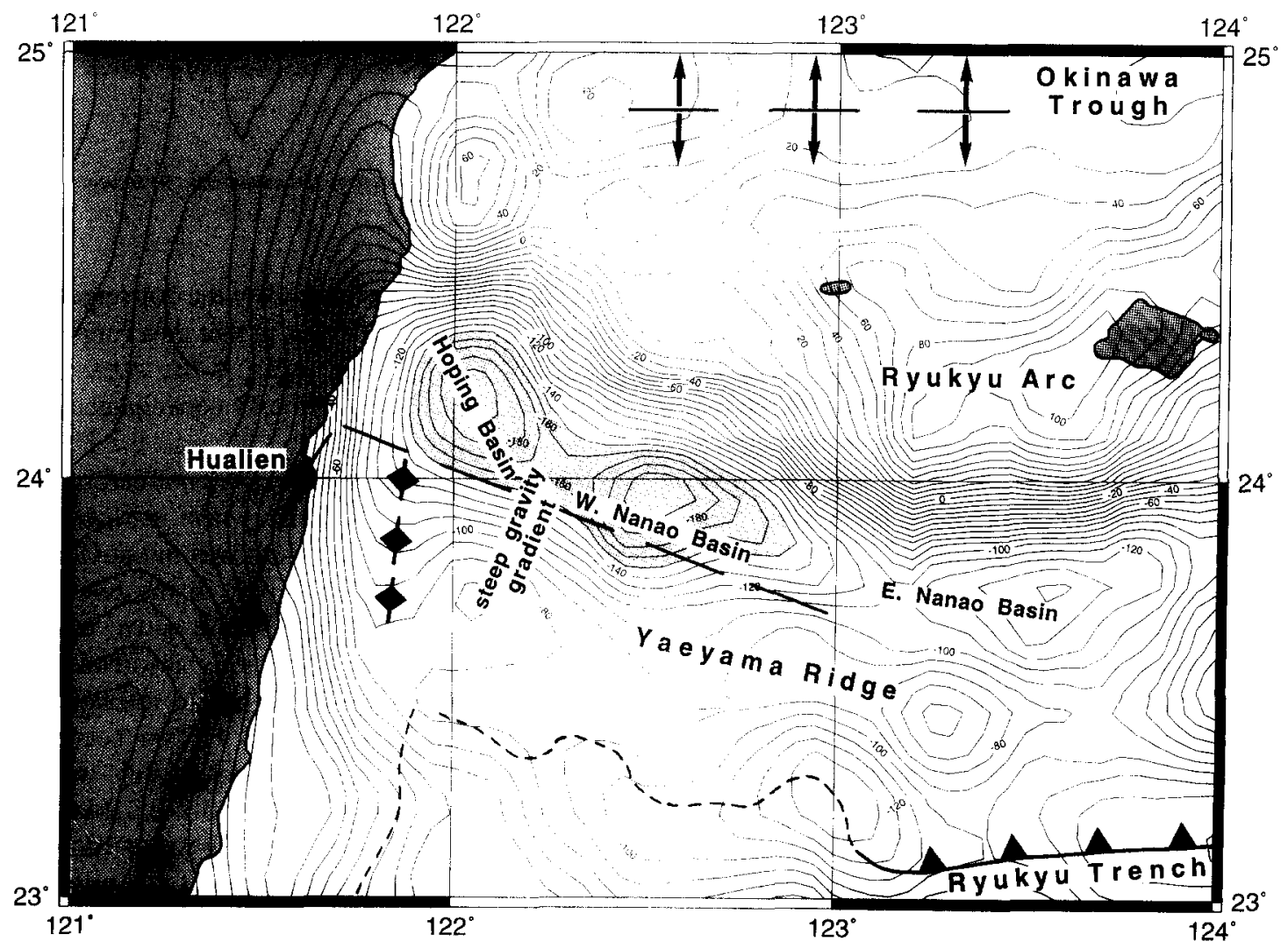

Fig. 11. Free-air anomaly map in the southern Ryukyu trench from Smith and Sandwell (1995) data base. Values of FAA less than -150 mGals are represented by a grey area. See legend of Fig. 9 for tectonic features. The dotted line outlines the base of the talus (Luzon arc and Yaeyama ridge). The gravity gradient shown on this map is steep relative to the differential bathymetry (less than $1 \mathrm{~km}$ ), but there exists a steeper gradient along the slope of the Ryukyu arc which is associated with $3 \mathrm{~km}$ of difference in depth. 
ridge (Figs. 5 and 11). A steep gravity gradient (120 mGals over $30 \mathrm{~km}$ ) trends WNW-ESE in the southwestern part of the sedimentary basins, even when there is less than $1000 \mathrm{~m}$ of differential depth. We thus conclude that this localized linear gravity gradient reflects a deep tectonic feature that could be caused by the non-isostatic pull force associated with the sinking of the northeastern part of the Philippine Sea plate (accelerated subduction) and probable dragging of the edge of the upper Ryukyu plate supporting the Suao Basin. The extreme low value is caused for a large part by the thick pile of sediment that fills the hole created by the tear fault.

\subsection{Additional constraints given by earthquakes}

The Hualien area is the most seismically active area in Taiwan (Yeh et al., 1991). Maps representing earthquake epicentres, like those in Fig. 12 (Font, 1996), show a swarm of earthquakes, shallower than $30 \mathrm{~km}$, remarkably aligned with the previous gravity low. The swarm is restricted to the West Nanao Basin and does not extend east of $123^{\circ} \mathrm{E}$, matching the extent of the gravity low. The surface trace of the tear fault represented in Fig. 9 has been drawn to match the gravity gradient and the swarm of earthquakes, because it cuts the subducting Philippine Sea plate, of which the top could be about $20 \mathrm{~km}$ deep in this area. The surface deformation may not totally reflect this deep tectonic feature. The seismic gap between the Hualien area and the West Nanao Basin might suggest that the fault is no more active near Taiwan and propagates to the southeast. Most focal mechanisms of earthquakes in this area show N-S compression but faulting expressions are not clear between gently dipping underthrusting, as expected beneath the forearc basement in a subduction zone, steeply dipping E-W, reverse faulting or conjugated subvertical strike-slip faulting (Wu, 1978; Font, 1996). Because the earthquakes are tightly scattered along the forearc and observed down to $30 \mathrm{~km}$, we suggest that they are related with a high-angle lithospheric fault. Maps of earthquake epicentres (Fig. 12) as well as hypocentre cross-sections clearly delineate the Benioff zone of the Philippine Sea plate north of Hualien (Wu et al., 1994). Seismicity occurs throughout much of the lithosphere down to a depth of $50 \mathrm{~km}$ under the Coastal Range. Uplift of the Cen- tral and Coastal Ranges is thus probably achieved by deforming the whole lithosphere (Wu et al., 1995). Tomographic images also favour the 'lithospheric buttress' hypothesis concerning the Philippine Sea plate south of Hualien (Rau and Wu, 1995; Wu et al., 1995).

Finally, seismicity and gravity data support the existence of a decoupling at the latitude of the Hoping Basin (Fig. 9). Kinematically, the suspected lithospheric tear fault must propagate toward the southeast as the Ryukyu subduction goes on. Present-day seismicity shows that the larger seismic events are located at the southeastern tip of the cluster of earthquakes (Fig. 12). The present situation is unstable because both Coastal and Central Ranges can not internally deform for a long period of time. The Huatung Basin will probably deform soon east of the Luzon arc through buckling and failure of the whole lithosphere, as attested by the NW-SE compressive stress recorded from earthquakes (Cheng et al., 1995).

\section{Evolutionary model for the 'junction area'}

Due to the lack of age constraints for the strata of the Hoping and Suao Basins, we can only speculate on absolute ages assuming that the first collision event in northern Taiwan occurred around 3 to 4 m.y. ago (see the discussion on the age of the collision above), but the relative chronology between events is better constrained.

(1) $\geq 5 \mathrm{Ma}$, Miocene or earliest Pliocene. The Suao Basin could have been deposited as early as in Miocene time (or even older) or as late as the recent collision phase in northern Taiwan, as a delta fan or a platform basin on top of the Ryukyu arc (Fig. 13). We say 'may' because the slightly diverging reflections observed in the Suao Basin can be attributed to syn-subsidence deposition (in this hypothesis, the upper strata might have been deposited during the first phase of subsidence) or as compaction effects due to loading by sediment (in this case, sedimentation may have occurred anytime before tectonism). Clastic sediments were supplied either from mainland China or from the nearby growing proto-Taiwan belt if deposition occurred during collision. If the convergence was NNW-SSE instead of WNW-ESE, as predicted by several authors, then a transform fault 


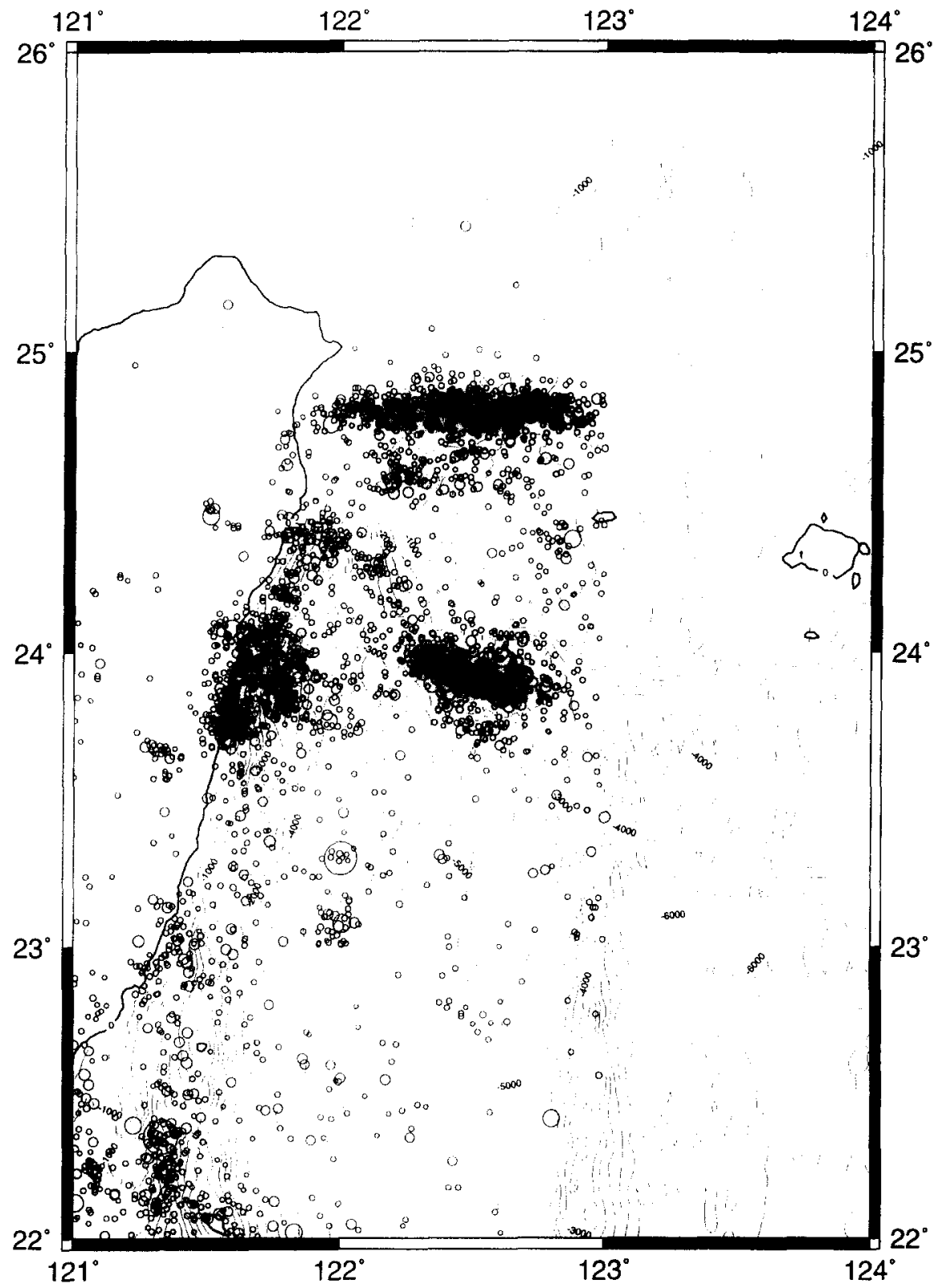

Fig. 12. Epicentres of earthquakes, recorded by the local network, shallower than $30 \mathrm{~km}$, superimposed on the bathymetric map after Font (1996). The data file ends along $123^{\circ} \mathrm{E}$, but it has been verified on other seismological maps that the two swarms of earthquakes (E-W in the Okinawa trough and WNW-ESE in the forearc basins) terminate at or west of $123^{\circ} \mathrm{E}$. The WNW-ESE swarm observed beneath the West Nanao Basin is attributed to the tear fault.

might have connected the E-W Ryukyu subduction zone with the Manila subduction zone at this time.

(2) $4 \mathrm{Ma}$, Early Pliocene. Depending on the northern extent of the Luzon arc and/or the occurrence of the previously accreted terrane of the Central Range, the first collisional event might be recorded as early as Early Pliocene in northern Taiwan. The former transform fault was reactivated into a lithospheric thrust when the convergence became more WNWESE-trending. The northern termination of the arc 
S.E. Lallemand et al. / Tectonophysics 274 (1997) 171-190
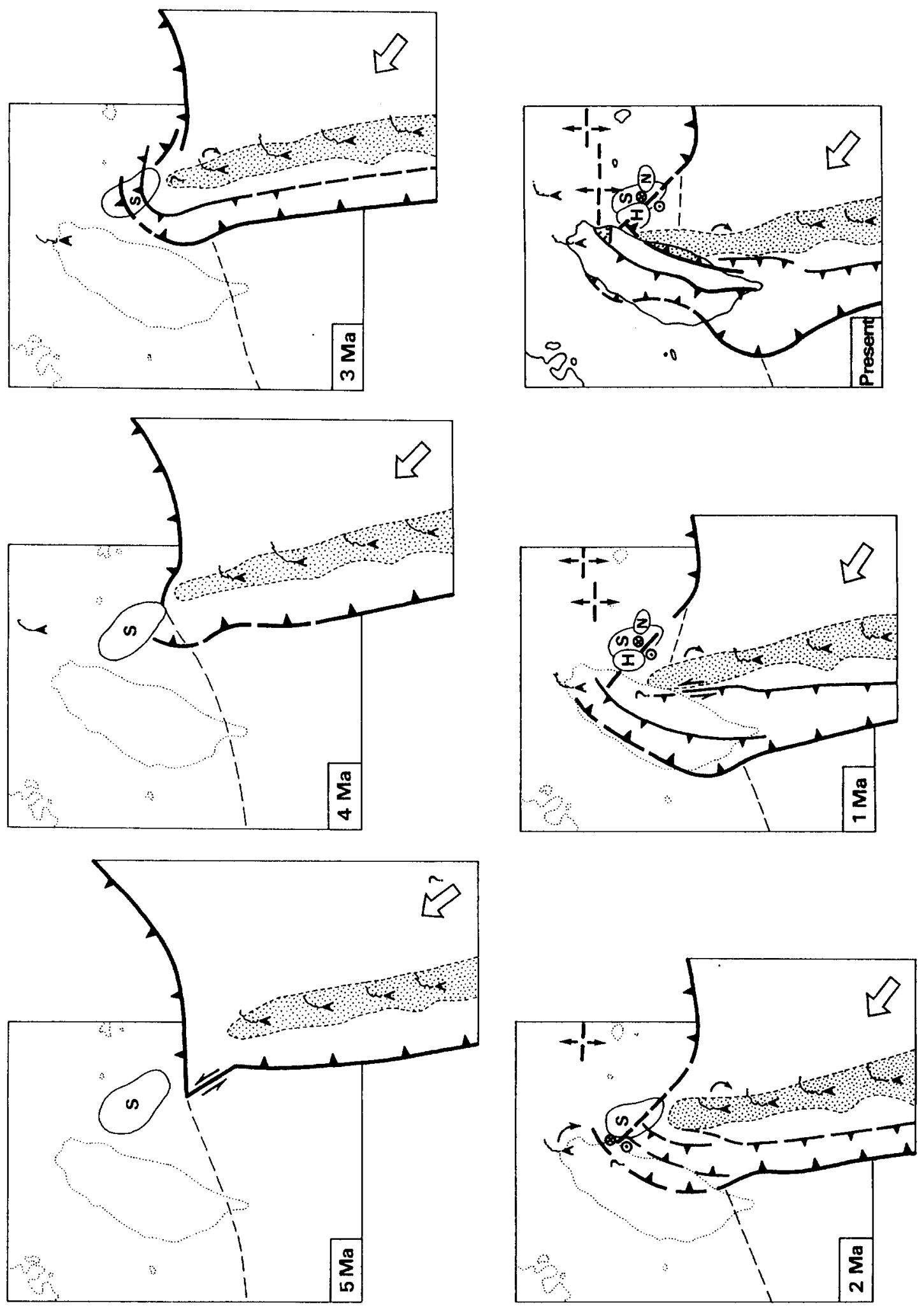

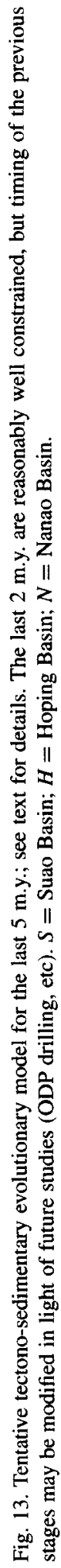


indented the margin rather than subducting beneath. thus preventing back-arc spreading in the western part of the Okinawa trough.

(3) $3 \mathrm{Ma}$, Late Pliocene. Indentation of the western end of the Ryukyu subduction zone proceeded and the Suao Basin shortened in a NW-SE direction through folding and thrusting as a result of the collision. Strike-slip or transform motion might accommodate the collision to the east of the indenter.

(4) $2 \mathrm{Ma}$, latest Pliocene. The shear stress reached the yield limit of the Philippine Sea plate because of the two opposite polarities of the subduction zones, i.e. eastward-dipping Manila subduction (locally preventing the Philippine Sea plate to subduct) against northward-dipping Ryukyu subduction. The Philippine Sea plate thus failed along a tear fault. which nucleated just north of the Luzon arc and then propagated toward the southeast along the direction of convergence. Vertical motion along the tear fault produced dramatic subsidence (about $3 \mathrm{~km}$ ) of the southwestern portion of the Suao Basin. which was located on the edge of the upper Ryukyu plate and was dragged down the subduction zone. The northern portion of the Philippine Sea plate sank rapidly beneath the growing Taiwan belt because it was decoupled from the northern Luzon arc. Such decoupling allowed the clockwise rotation of northeast Taiwan by more than $15^{\circ}$ (Lue, 1989) and back-arc opening resumed in the southern Okinawa trough (Miki, 1995). The part of the Yaeyama ridge that is now located in the 'junction area' experienced uplift because it is carried on top of the non-subducting section of the Philippine Sea plate. This uplift favoured trapping of sediment in the Hoping Basin. South of the tear fault, the Philippine Sea plate acted as a buttress, pushing the growing Taiwan fold-and-thrust belt to the northwest. The arc deformed internally through shortening. thickening. and block rotation. North of the tear fault, the belt may have undergone clockwise block rotations as a result of the differential motion of northern Taiwan.

(5) $1 \mathrm{Ma}$, mid-Pleistocene. The Hoping Basin formed during this time interval as a proximal channelized basin. Trench roll-back generated a new episode of extension within the overriding plate above the subducting slab and thus back-arc rifting resumed east of Ilan Plain (Sibuet et al.. 1995) while nearby collision continued to proceed south- ward as attested by southward propagation of clockwise block rotation within the Coastal Range (Lee et al.. 1991). This was possible because of decoupling allowed by the tear fault. The part of the 'junction area' south of the tear fault is passively transported with the Philippine Sea plate and progressively tilted toward the southeast, due to the overthrusting motion of the plate. which could explain why the Hualien Canyon appears to migrate to the east. The southwestern part of the Hoping Basin is thus continuously uplifted, because of tilting of its basement to the northeast, and locally deformed, where it approaches the surface trace of the tear fault, which probably intersects the Hsincheng ridge.

(6) Present. Today, the Yaeyama ridge has been uplifted by several hundred metres (from $2600 \mathrm{~m}$ just west of the actual Gagua ridge to $2300 \mathrm{~m}$ near the Hualien Canyon, whereas the ridge culminates at a depth of $3000 \mathrm{~m}$ just to the east of the presumed tear fault, except above the subducting Gagua ridge, $2300 \mathrm{~m}$ ). The tear fault is less active beneath the Hoping Basin and propagates toward the southeast. The propagation causes the subsidence of the West Nanao Basin which is now depositional. Erosion prevails in the Hoping Basin. The Luzon arc is actively deforming, as attested by the high seismicity down to $50 \mathrm{~km}$. As mentioned earlier. the present situation is mechanically unstable and the Philippine Sea plate should deform behind the Luzon arc. Northsouth extension in the Okinawa trough now reaches Taiwan in the area of the Ilan Plain.

\section{Conclusions}

This study provides additional constraints that must be taken into account for the tectono-sedimentary evolution of the area offshore northeast Taiwan. Time constraints are lacking, but dating of events could be provided by deep-sea drilling. A relative chronology has been proposed, however, for the succession of events, which can be refined with absolute ages of basin filling and tectonic phases. The main results of this study are the recognition of two superposed basins that were previously unknown and the dramatic subsidence and tilting of the Suao Basin. an explanation for which guided us toward the tear fault model. This model has then be tested with regards to surface seismic expression on both sides of 
the presumed tear fault. An extremely low free-air gravity anomaly could result from the non-isostatic force associated with the sinking of the Philippine Sea plate on the northern side of the tear fault and the dragging of the upper plate supporting the subsided sedimentary basin. The subsiding area is now moving toward southeast as the tear fault propagates and affects the West Nanao Basin. A swarm of shallow earthquakes beneath the West Nanao Basin aligns with the gravity low and could correspond to a steeply E-W-dipping reverse fault. If right, the tear fault might explain how collision can proceed only tens of kilometres from subduction.

\section{Acknowledgements}

Discussions with Alexander Chemenda and Jacques Malavieille in laboratory, Neil Lundberg and Donald Reed onboard the R/V M. Ewing, Jacques Angelier and Francis Wu allowed us to test the ideas and improve this paper. Shu-Juang Lin and Shu-Wen Lee processed the seismic lines at IONTU (Institute of Oceanography of the National Taiwan University) in Taipei. The crew of $R / V$ Ocean Researcher $I$ is also thanked. J.F. Stéphan kindly provided us the original seismic lines of the POP II cruise. G. Garcia and A. Delplanque illustrated some of the figures. Travel and local expenses were supported by FIT (French Institute in Taipei), NSC (National Science Council of Taiwan) and INSU-CNRS for the Sept. 95 MCS cruise.

\section{References}

Angelier, J., Bergerat, F., Chu, H.-T. and Lee, T.-Q., 1990. Tectonic analysis and the evolution of a curved collision belt: the Hsüehshan Range, northern Taiwan. Tectonophysics, 183: $77-96$.

Angelier, J., Lee, J.-C., Chu, H.-T., Lu, C.-Y., Fournier, M., Hu, J.-C., Lin, N.-T., Deffontaines, B., Delcaillau, B., Lacombe, O. and Lee, T.-Q., 1995. Crustal extension in an active orogen. In: H.-H. Tsien (Editor), Active Collision in Taiwan, Symp. Proc., Taipei, March 22-23, 1995: 25-32.

Barrier, E., 1985. Un grand accident actif: la faille de la vallée longitudinale de Taïwan (Taïwan, République de Chine). Rev. Géol. Dyn. Géogr. Phys., 26, 1: 43-58 (with English abstract).

Barrier, E. and Angelier, J., 1986. Active collision in eastern Taiwan: the Coastal Range. Tectonophysics, 125, 1-3: 9-72.

Barrier, E. and Müller, C., 1984. New observations and discussion on the origin and age of the Lichi melange. Mem. Geol. Soc. China, 6: 303-326.
Bowin, C., Lu, R.S., Lee, C.S. and Shouten, H., 1978. Plate convergence and accretion in Taiwan-Luzon region. Am. Assoc. Pet. Geol., 62: 1645-1672.

Chemenda, A.I., 1995. Possible evolutionary model for the Taiwan collision explaining rock exhumation and extension in the Central Range. In: H.-H. Tsien (Editor), Active Collision in Taiwan, Symp. Proc., Taipei, March 22-23, 1995: 41-47.

Cheng, S.-N., Yeh, Y.-T. and Lee, C.-T., 1995. A stress map in Taiwan. In: H.-H. Tsien (Editor), Active Collision in Taiwan, Symp. Proc., Taipei, March 22-23, 1995: 57-69.

Chi, W.-R., Namson, J. and Suppe, J., 1981. Stratigraphic record of plate interactions in the Coastal Range of eastern Taiwan. Mem. Geol. Soc. China, 4: 155-194.

Deramond, J., Souquet, P., Delcaillau, B., Angelier, J., Chu, H.T., Lee, J.F., Lee, T.Q., Liew, P.M., Lin, T.S. and Teng, L., 1995. Determining the collision belt evolution from foreland tectono-sedimentary records. A case history: the Foothills of Taiwan. In: H.-H. Tsien (Editor), Active Collision in Taiwan, Symp. Proc., Taipei, March 22-23, 1995: 99-104.

Font, Y., 1996. Etude de la sismicité au nord-est de Taiwan: conséquences sur la déformation de la plaque Philippine au front de la zone de collision. DEA report, Montpellier University, June 1996, 50 pp.

Huang, C.-Y., Yuan, P.-B., Song, S.-R., Lin, C.-W., Wang, C., Chen, M.-T., Shyu, C.-T. and Karp, B., 1995. Tectonics of short-lived intra-arc basins in the arc-continent collision terrane of the Coastal Range, eastern Taiwan. Tectonics, 14(1): 19-38.

Juang, W.S. and Bellon, H., 1984. The potassium-argon dating of andesites from Taiwan. Proc. Geol. Soc. China, 27: 86-100.

Lallemand, S.E., Liu, C.-S. and Lin, S.-J., 1995. Behaviour of the Ryukyu forearc sliver in the wake of the indenting northern Luzon Arc (East of Taiwan). In: H.-H. Tsien (Editor), Active Collision in Taiwan, Symp. Proc., Taipei, March 22-23, 1995 : 167-175.

Lee, T.Q., Kissel, C., Barrier, E., Laj, C. and Chi, W.R., 1991. Paleomagnetic evidence for a diachronic clockwise rotation of the Coastal Range, eastern Taiwan. Earth Planet. Sci. Lett., 104: 245-257.

Lin, S.-J., 1994. Bathymetry and seismic characteristics offshore Eastern Taiwan, and its tectonic implication. Master thesis, National Taiwan University, 78 pp. (in Chinese).

Liu, C.-S., Lin, S.-J. and Lallemand, S.E., 1997. Structural variations at the south-western tip of the Ryukyu trench-forearc region. TAO (submitted).

Lu, C.-Y. and Hsu, K.J., 1992. Tectonic evolution of the Taiwan Mountain Belt. Pet. Geol. Taiwan, 27: 21-46.

Lue, Y.T., 1989. The paleomagnetic study in the fold-thrust belt, northern Taiwan, and its tectonic implications. $\mathrm{PhD}$ thesis, National Taiwan University, $226 \mathrm{pp}$. (in Chinese).

Miki, M., 1995. Two-phase opening model for the Okinawa Trough inferred from paleomagnetic study of the Ryukyu arc. J. Geophys. Res., 100 (B5): 8169-8184.

Rau, R.-J. and Wu, F.T., 1995. Tomographic imaging of lithospheric structures under Taiwan. Earth Planet. Sci. Lett., 133: 517-532.

Seno, T., Stein, S. and Gripp, A.E., 1993. A model for the 
motion of the Philippine Sea plate consistent with NUVEL-1 and geologic data. J. Geophys. Res., 98. B 10: 17.941-17.948.

Shemenda, A.I., 1994. Subduction: Insights from Physical Modeling. Kluwer Academic Publishers, Dordrecht, $215 \mathrm{pp}$.

Sibuet, J.-C., Hsu, S.-K., Shyu, C.-T. and Liu, C.-S.. 1997. Structural and kinematic evolutions of the Okinawa Trough back-arc basin. In: B. Taylor (Editor), Back-are Basins: Tectonics and Magmatism. Plenum, New York, pp. 343-378.

Smith, W.H.F. and Sandwell, D.T., 1995. Marine gravity tield from declassified Geosat and ERS1 altimetry. 1995 AGU Fall Meeting, EOS, 7: 156

Stéphan, J.F., Rangin, C., Blanchet, R., Baladad, D.. Bouysse. P., Chen, M.F., Chotin, P., Collot, J.-Y., Daniel, J., Drouhot, J.M., Marsset, B., Pelletier, B., Richard, M. and Tardy, M., 1990. Campagne POP 2: Passage subduction-collision aux extrémités des fosses de Ryukyu et de Manille. In: Tour du Monde 'Jean-Charcot', 1983-1987. Oceanol. Acta, Vol. Spéc.. 10: 118-125.

Suppe, J., 1981. Mechanics of mountain building and metamorphism in Taiwan. Mem. Geol. Soc. China, 4: 67-89.

Teng, L., 1990. Geotectonic evolution of late Cenozoic arc-continent collision in Taiwan. Tectonophysics, 183: 57-76.

Teng, L.S., Chen, C.H.. Wang, W.S., Liu, T.K., Juang, W.S. and Chen, J.C., 1992. Plate kinematic model for late Cenozoic arc magmatism in northern Taiwan. J. Geol. Soc. China, 35, I: $1-18$.

Wu, F.T., 1978. Recent tectonics of Taiwan. J. Phys. Earth, 26 : S265-299.

Wu, F.T., Salzberg, D. and Rau, R.J., 1991. The modern orogeny of Taiwan. In: Taicrust Workshop Proceedings, June 10-12, 1991, Taipei, pp. 49-62.

Wu, F.T., Yeh, Y.H., Rau, R.J., Yen, H.Y., Salzberg, D., Yu, S.B., Liu, C.C. and Lee, T.Q., 1994. Results of studies on modern Taiwan orogeny. In: Commemorative Seminar of President Wu Tayou's Retirement. Academia Sinica, Nankang. Taipei, pp. 45-77 (in Chinese).

Wu, F.T., Rau, R.-J. and Salzberg, D., 1995. Are we ready to critically evaluate hypotheses of Taiwan Orogeny? In: H.-H. Tsien (Editor), Active Collision in Taiwan, Symp. Proc., Taipei, March 22-23, 1995: 293-300.

Yeh. Y.H., Barrier, E., Lin, C.H. and Angelier, J., 1991. Stress tensor analysis in the Taiwan area from focal mechanisms of earthquakes. Tectonophysics, 200: 267-280.

Yen. H.-Y., Liang. W.-T., Kuo, B.-Y., Yeh, Y.-H., Liu, C.-S., Reed. D., Lundberg, L., Su, F.-C. and Chung, H.-S., 1995. A regional gravity map for the subduction-collision zone near Taiwan. TAO, 6(2): 233-250.

Yu. S.-B. and Chen, H.-Y., 1994. Global Positioning System measurements of crustal deformation in the Taiwan arc-continent collision zone. TAO, 5(4): 477-498.

Yu. S.-B., Chen, H.-Y. and Kuo, L.-C., 1995. Velocity field of GPS stations in the Taiwan area. In: H.-H. Tsien (Editor), Active Collision in Taiwan, Symp. Proc., Taipei, March 22-23. 1995: 317-327.

Yu. S.-B., Chen, H.-Y. and Kuo, L.-C., 1997. Velocity field of GPS stations in the Taiwan area. In: S.E. Lallemand and H.-H. Tsien (Editors), Active Collision in Taiwan. Tectonophysics. 274: $41-59$ (this issue). 